\title{
PEMISAHAN JENIS PIGMEN KAROTENOID DARI KEPITING Grapsus SP JANTAN MENGGUNAKAN METODE KROMATOGRAFI KOLOM
}

\section{(Separation Types of Carotenoid Pigment From Male Crab of Grapsus sp. Using Column Chromatography Method)}

\author{
Anisa E.T. Silaa1, Darus Sa'adah J. Paransa ${ }^{1 *}$, Antonius P. Rumengan, \\ Kurniati Kemer ${ }^{1}$, Natalie D. C. Rumampuk ${ }^{1}$, Hengky Manoppo ${ }^{2}$ \\ 1. Program Studi IImu Kelautan, Fakultas Perikanan dan IImu Kelautan, Universitas Sam \\ Ratulangi, Manado. \\ 2. Program Studi Budidaya Perairan, Fakultas Perikanan dan IImu Kelautan, Universitas \\ Sam Ratulangi, Manado. \\ ${ }^{*}$ Corresponding author : Darus Saadah J. Paransa, email : darusparansa@unsrat.ac.id
}

\begin{abstract}
Absract
Grapsus sp crab has a greenish black body color and also known as stone crab. Crabs in the genus Grapsus sp have a swift movement, long legs, they do not have swimming legs and have small reddish purple or purple-orange color, claws on the body of this crab indicated the presence of pigments such as carotenoid pigments. Carotenoid pigments are one form of secondary metabolites which consist of carotene and xanthophyll groups. Carotenoid pigments are present in yellow, orange or orange red which are also found in crabs. Separation of carotenoid pigments can be done using the TLC method, High Performance Liquid Chromatography (HPLC) and Column Chromatography (CC). The purpose of this study was to determine the type of carotenoid pigment from male Grapsus sp crab extract using the Column Chromatography separation method. From the results of this study, the carotenoid pigment content in the 1,2 and 3 carapace was $46,85 \mu \mathrm{g}, 39 \mu \mathrm{g}$, and 33,14 $\mu \mathrm{g}$. The carotenoid pigment concentrations in carapace extracts 1,2 and 3 are $25,38 \mu \mathrm{g} / \mathrm{g}, 23,4 \mu \mathrm{g} / \mathrm{g}$ and 5,11 $\mu \mathrm{g} / \mathrm{g}$. From the results of the separation using the column chromatography method, the type of carotenoid pigment identified from the carapace extract of Grapsus sp male is $\beta$-Carotene, Ekinenon, Astaxantine, Kantaxantine and Astacen.
\end{abstract}

Keywords: Grapsus sp, Carotenoid, Column Chromatography

Abstrak

Kepiting Grapsus sp memiliki warna tubuh hitam kehijauan dan dikenal dengan nama kepiting batu. Kepiting dalam genus Grapsus sp memiliki gerakkan yang cekatan, mempunyai kaki yang panjang, tidak memiliki kaki renang dan memiliki capit berukuran kecil yang berwarna ungu kemerahan atau ungu-oranye warna pada tubuh kepiting ini mengindikasikan adanya kandungan pigmen seperti pigmen karotenoid. Pigmen karotenoid merupakan salah satu bentuk metabolit sekunder yang yang terdiri dari golongan karoten dan xantofil. Pigmen karotenoid hadir dalam warna kuning, oranye, atau merah oranye, yang juga ditemukan pada kepiting. Pemisahan pigmen karotenoid dapat dilakukan dengan menggunakan metode KLT, Kromatografi Cair Kinerja Tinggi (KCKT) dan Kromatografi Kolom (KK). Tujuan dari penelitian ini adalah untuk mengetahui jenis pigmen karotenoid dari ekstrak kepiting Grapsus sp Jantan dengan menggunakan metode pemisahan Kromatografi Kolom. Dari hasil penelitian ini, didapatkan kandungan pigmen karotenoid pada karapas 1,2 dan 3 adalah 46,85 $\mu \mathrm{g} 39 \mu \mathrm{g}$, dan $33,14 \mu \mathrm{g}$. Konsentrasi pigmen karotenoid pada ekstrak karapas 1,2 dan 3 adalah 25,38 $\mu \mathrm{g} / \mathrm{g}$, 23,4 $\mu \mathrm{g} / \mathrm{g}$ dan $5,11 \mu \mathrm{g} / \mathrm{g}$. Hasil pemisahan menggunakan metode pemisahan kromatografi kolom didapatkan ekstrak karapas kepiting Grapsus sp jantan memiliki jenis pigmen $\beta$-Karoten, Ekinenon, Astaxantin, Kantaxantin dan Astasen.

Kata kunci: Grapsus sp, Karotenoid, Kromatografi Kolom, 


\section{PENDAHULUAN}

Krustasea merupakan salah satu kelas terbesar dari filum Arthropoda. Kepiting adalah salah satu organisme yang termasuk kedalam kelas Krustasea. Karapas krustasea memiliki ciri khas warna yang menarik dan dalam siklus hidupnya dapat melakukan pergantian kulit atau molting (Bliss, 1982). Warna yang menarik mengindikasikan adanya kandungan pigmen karotenoid. Pigmen karotenoid merupakan salah satu bentuk metabolit sekunder yang yang terdiri dari golongan karoten dan xantofil. Pigmen karotenoid hadir dalam warna kuning, oranye, atau merah oranye, yang ditemukan pada kepiting (RodriguezAmaya dan Kimura, 2004). Menurut Packer (1992) pigmen karotenoid tidak dapat disintesis secara de novo oleh kepiting dan proses sintesis pigmen karotenoid diperoleh melalui makanannya. Selanjutnya menurut Robbert and Barnes (1985), salah satu fungsi pigmen karotenoid berpengaruh pada pertumbuhannya melalui proses molting. Molting pada krustasea adalah proses pergantian cangkang, yang terjadi karena pertumbuhan daging yang bertambah besar sedangkan cangkang krustasea tidak ikut bertumbuh karena bersifat kaku. Tahapan molting berpengaruh pada pertumbuhan kepiting sehingga kepiting memiliki bentuk tubuh, ukuran dan warna pada karapas yang berbeda tergantung pada jenisnya (Skinner and Kumari, 1992). Salah satu contoh spesies yang masuk ke dalam kelompok kepiting adalah Grapsus sp (Poore, 2004).

Grapsus sp. memiliki warna tubuh hitam kehijauan dan dikenal dengan nama kepiting batu. Kepiting dalam genus Grapsus sp memiliki gerakkan yang cekatan, mempunyai kaki yang panjang, tidak memiliki kaki renang dan memiliki capit berukuran kecil yang berwarna ungu kemerahan atau ungu-oranye (Poupin and Juncker, 2010). Menurut Majchaceep, (1989) Grapsus sp memiliki ciri pada warna capitnya yaitu berwarna unguoranye).

Krustasea memiliki pigmen karotenoid yang terdapat pada lapisan epidermis dan karapas krustasea adalah pigmen astaksantin (Mantiri dan Kepel, 1999). Pemisahan menggunakan Kromatografi Lapis Tipis (KLT) dengan beda larutan pengembang dari ekstrak pigmen total Grapsus albolineatus betina, ditemukan jenis pigmen yang berbeda. Penelitian Abdullah $d k k$ (2018), jenis pigmen karotenoid seperti $\beta$-karoten, $\beta$ kriptoksantin, astaksantin dan astasen yang terkandung pada kepiting Grapsus albolineatus betina dipisahkan menggunakan metode KLT.

Pemisahan pigmen karotenoid dapat dilakukan dengan menggunakan metode KLT, Kromatografi Cair Kinerja Tinggi (KCKT) dan Kromatografi Kolom (KK) (Bintang, 2010). Hasil penelitian Zeak dkk (2019), pemisahan menggunakan Kromatografi Kolom dari ekstrak pigmen total karapas kepiting Grapsus sp teridentifikasi 3 jenis pigmen yaitu ekinenon, kantaxantin, dan astaxantin

Stahl (1985), menyatakan bahwa prinsip dari kromatografi kolom adalah adanya perbedaan daya serap dari masing-masing komponen yang akan diuji. Sampel dilarutkan dalam pelarut kemudian dimasukkan ke dalam kolom kromatografi melalui puncak kolom dan larutan tersebut mengalir ke dalam fase diam yang kemudian bermigrasi ke bawah sambil terjadi pemisahan.

Vilchez (2011) mengkonfirmasi manfaat karotenoid (lutein, $\beta$-karoten, kantaxantin dan zeaxanthin) bagi kesehatan manusia, dimana manfaat karotenoid yang paling terkait adalah sifat antioksidannya untuk mekanisme respons anti-inflamasi, antikanker, antibakteri, dan sebagai pro vitamin $\mathrm{A}$.

\section{METODE PENELITIAN}

\section{Waktu dan Tempat Penelitian}

Pada penelititian ini pengambilan sampel diambil dari lokasi pesisir pantai Desa Ranowangko Kecamatan Tombariri Kabupaten Minahasa, Sulawesi Utara. Sampel kepiting ditangkap pada malam hari menggunakan tangan dengan alat bantu berupa senter untuk penerangan dan sarung tangan untuk melindungi 
tangan. Pengambilan sampel dilakukan pada minggu terakhir bulan Maret 2019, sedangkan untuk tahap ekstraksi sampel dilakukan pada awal bulan April 2019 di

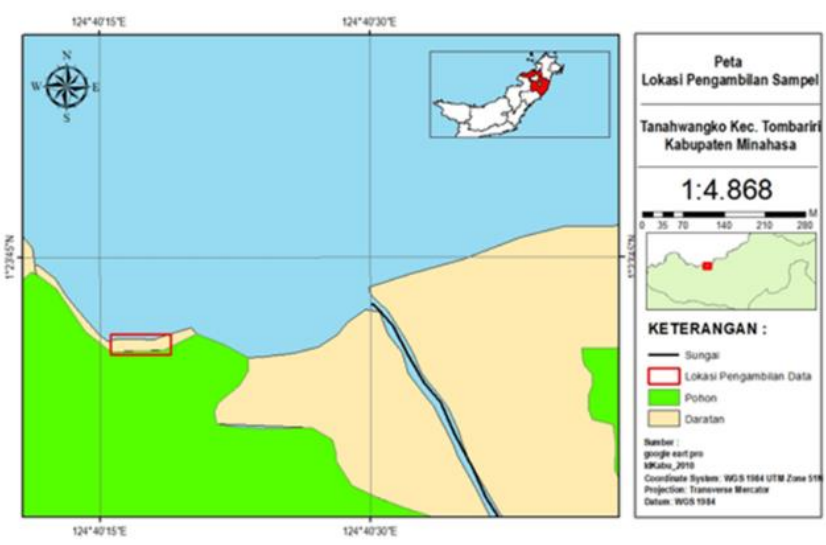

Gambar 1. Peta Lokasi Pengambilan Sampel

Sumber : Google Earth Pro

\section{Penanganan Sampel}

Sampel kepiting yang berhasil ditangkap dimasukkan ke dalam wadah yang telah berisi sedikit air laut, selanjutnya sampel kepiting dibawa ke Laboratorium Teknologi Akuakultur Fakultas Perikanan dan IImu Kelautan UNSRAT untuk dilakukan tahap identifikasi menggunakan petunjuk dari Majchacheep (1989) dan Poupin and Juncker (2010). Kepiting Grapsus sp jantan kemudian dibersihkan dan dibedah untuk mendapatkan organ karapas yang akan digunakan dalam penelitian.

\section{Analisis Stadium Molting}

Bagian uropoda dipotong tipis dan diletakkan diatas kaca preparat selanjutnya diamati di bawah mikroskop Olympus tipe CX-41 dengan pembesaran $20 \times$ untuk menentukan tahapan stadium molting. Selanjutnya hasil pengamatan dibandingkan dengan Skinner (1962); Skinner and Kumari (1992).

\section{Tahapan Ekstraksi}

Organ karapas yang telah
dipisahkan ditimbang menggunakan
timbangan analitik kemudian direndam
menggunakan HCL $2 \mathrm{~N}$ selama $3-5$ menit
untuk melunakkan karapas dan

memisahan senyawa kitin dan karotenoprotein yang terkandung dalam karapas. Tahap selanjutnya, karapas digerus menggunakan lumpang dan alu selama penggerusan ditambahkan larutan aseton sebanyak $15 \mathrm{ml}$ yang ditambahkan secara bertahap. Setelah itu hasil ekstrak dimasukkan ke dalam labu pemisah yang sudah ada kertas saring pada bagian atasnya kemudian ditambahkan larutan Heksan sebanyak $25 \mathrm{ml}$ selanjutnya dikocok kemudian ekstrak pigmen total karapas ditampung ke dalam botol.

\section{Pemisahan Ekstrak Pigmen Total Menggunakan Kromatografi Kolom}

Pada penelitian ini digunakan metode kering, dengan tahapan sebagai berikut: Media kolom kromatografi dimasukkan kapas dengan ukuran kecil yang diletakkan di bawah media kolom agar bubuk silika tidak keluar dari kolom. Bubuk silika dipanaskan dalam oven kemudian dimasukkan ke dalam kolom kromatografi sebagai fase diam dan larutan pengembang sebagai fase gerak. Bubuk silika di dalam kolom kromatografi dibasahi dengan larutan pengembang Heksan dan Aseton sebagai fase gerak yang bertujuan.

Setelah bubuk silika dibasahi dengan larutan pengembang kemudian ekstrak pigmen total sampel karapas dimasukkan pada permukaan kolom kromatografi menggunakan pipet tetes. Selama pemisahan pigmen kerotenoid berlangsung basahi bubuk silika dibasahi terus dengan larutan pengembang. Hasil pemisahan tersebut membentuk disebut fraksi-fraksi. Masing masing fraksi ditampung kedalam botol sampel dan dilanjutkan dengan penentuan serapan maksimum spektrofotometer UV-Vis diantara panjang gelombang $380-550 \mathrm{~nm}$. 
HASIL DAN PEMBAHASAN

\section{Hasil Identifikasi Sampel}

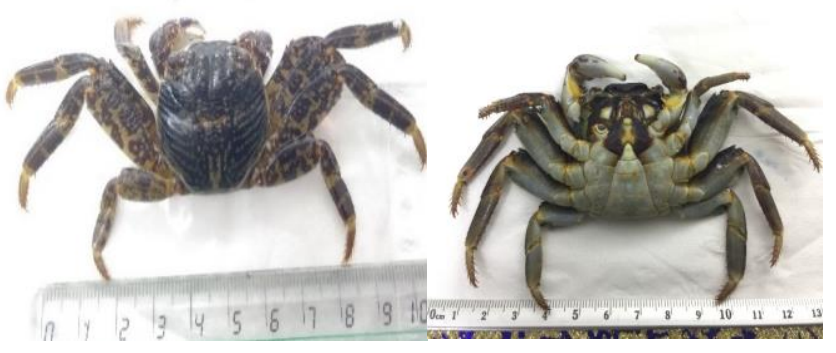

Gambar 2. Sampel Grapsus sp

Sumber : Dokumen Pribadi

Sampel yang diambil teridentifikasi sebagai kepiting Grapsus sp. Kepiting Grapsus sp banyak ditemukan di teluk Manado pada daerah pantai berbatu. Berdasarkan hasil penelitian Paransa $d k k$, (2019) salah satu spesies yang teridentifikasi hidup di pantai teluk Manado adalah spesies Grapsus albolineatus Latreille in Milbert, 1812 yang identifikasi melalui bentuk morfologi dan DNA. Menurut petunjuk Majchacheep (1989) Grapsus sp memiliki ciri-ciri sebagai berikut : Memiliki sepasang capit kecil berwarna keunguan, pada bagian dorsal karapas memiliki garis linier berwarna hijau kehitaman, dan memiliki bulatan berwarna oranye pada bagian tengahnya. Memiliki 4 pasang kaki jalan yang panjang tanpa kaki renang dan pasangan kaki jalan pertama paling pendek diantara yang lainnya, serta memiliki bulu-bulu yang melekat pada parapodia. Pasangan kakinya bercorak bulatan tidak teratur dan berwarna hijau kehijauan-oranye kecoklatan dan terdapat bintikan berwarna oranye pada bagian kaki. Sampel kepiting berkelamin jantan pada bagian abdomennya yang segitiga meruncing.

\section{Hasil Analisis Stadium Molting}

Sampel yang digunakan adalah sebanyak 3 sampel yang berada pada stadium molting yang sama yaitu pada stadium molting $\mathrm{C} 1$

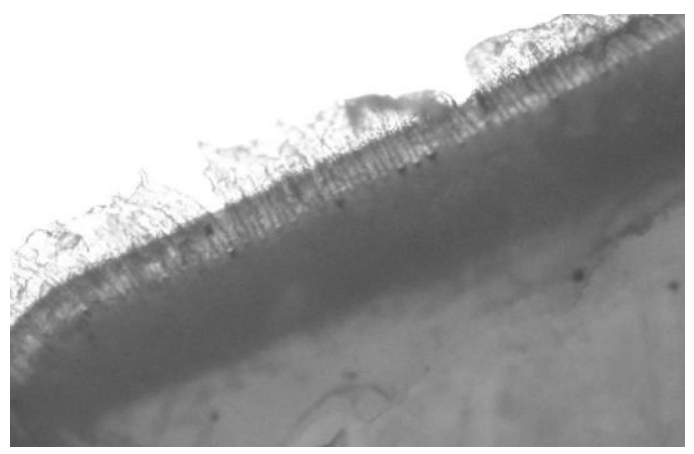

Gambar 3. Stadium Molting C1 Kepiting Grapsus sp Jantan

\section{Hasil Kandungan Pigmen Dan Konsentrasi Pigmen Total}

Serapan spektrofotometer UV-Vis diantara panjang gelombang $380-550$ nm pada ekstrak pigmen total membentuk puncak serapan seperti yang tampak pada Gambar 4.

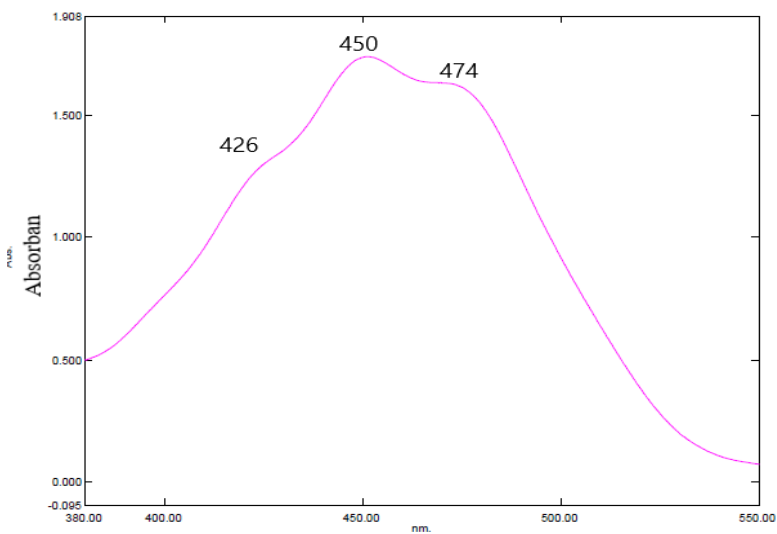

Gambar 4. Spektogram Ekstrak Pigmen Total Karapas Kepiting Grapsus sp

Bentuk spektogram dari pigmen total karapas kepiting Grapsus sp. (Gambar 4) memiliki tiga puncak gelombang dengan serapan maksimum spektrofotometer 426, 450 dan $474 \mathrm{~nm}$. Berdasarkan punvak serapan maksimum spektrofotometer UV-Vis pada ekstrak pigmen total organ karapas kepiting Grapsus sp dapat ditentukan nilai kandungan (Q) dan konsentrasi pigmen (C) berdasarkan rumus matetamtis Britton et.al (1995) seperti yang tampak pada Tabel 1. 
Tabel 1.Nilai Kandungan Dan Konsentrasi Pigmen Pada Sampel Kepiting Grapsus sp Jantan.

\begin{tabular}{|l|c|c|}
\hline Sampel & $\begin{array}{c}\text { Konsentrasi } \\
\text { Pigmen }(\mathbf{C}) / \mu \mathbf{g} / \mathbf{g r} \\
\text { berat residu kering }\end{array}$ & $\begin{array}{c}\text { Kandungan } \\
\text { Pigmen } \\
(\mathbf{Q}) /(\mu \mathbf{g})\end{array}$ \\
\hline Karapas 1 & 25,38 & 46,85 \\
\hline Karapas 2 & 23,4 & 39 \\
\hline Karapas 3 & 5,11 & 33,14 \\
\hline
\end{tabular}

Konsentrasi ekstrak pigmen total tertinggi pada masing-masing karapas kepiting Grapsus sp ada pada sampel karapas 1 dengan total konsentrasi 25,38 $\mu \mathrm{g} / \mathrm{gr}$ selanjutnya diikuti sampel karapas 2 dan sampel karapas ke 3.

Kandungan pigmen total tertinggi dari masing-masing karapas kepiting Grapsus sp ada pada sampel karapas 1 dengan nilai $46,85 \mu \mathrm{g}$, diikuti sampel karapas ke-2 dan sampel karapas ke-3. Pada sampel karapas 3 nilai konsentrasi dan kandungan pigmennya lebih rendah dari sampel karapas 1 dan 2 hal ini diasumsikan pigmen karotenoid terkonsentrasi pada organ lain. Menurut Poore (2004), pigmen karotenoid pada krustasea terdapat pada organ karapas, lapisan epidermis, hepatopankreas, hemosianin dan gonad. Pada penelitian ini, konsentrasi dan kandungan pigmen karotenoid pada ekstrak pigmen total karapas kepiting Grapsus sp menunjukkan adanya perbedaan konsentrasi pigmen. Menurut Moaka (2011), perbedaan konsentrasi karapas diduga karena dipengaruhi oleh makanan, metabolisme pigmen karotenoid pada krustasea diperoleh melalui makanannya.

\section{Hasil Pemisahan Ekstrak Pigmen Total Karapas Menggunakan Kromatografi Kolom}

$\begin{array}{llr}\text { Dari hasil } & \text { pemisahan } \\ \text { menggunakan kromatografi } & \text { kolom, } \\ \text { berhasil didapatkan } 5 \text { fraksi } & \text { yang } \\ \text { ditampilkan pada Tabel } 2 . & & \end{array}$

\section{Fraksi 1}

Fraksi 1 terbentuk tiga puncak gelombang dengan pucak serapan spektrofotometer pada panjang gelombang 425, 448, $471 \mathrm{~nm}$ dan menghasilkan warna kuning. Menurut Britton et al (1995) pigmen dengan tiga puncak serapan tersebut teridentifikasi sebagai pigmen $\beta$-Karoten. Pigmen karoten mayor pada krustasea adalah pigmen $\beta$-Karoten

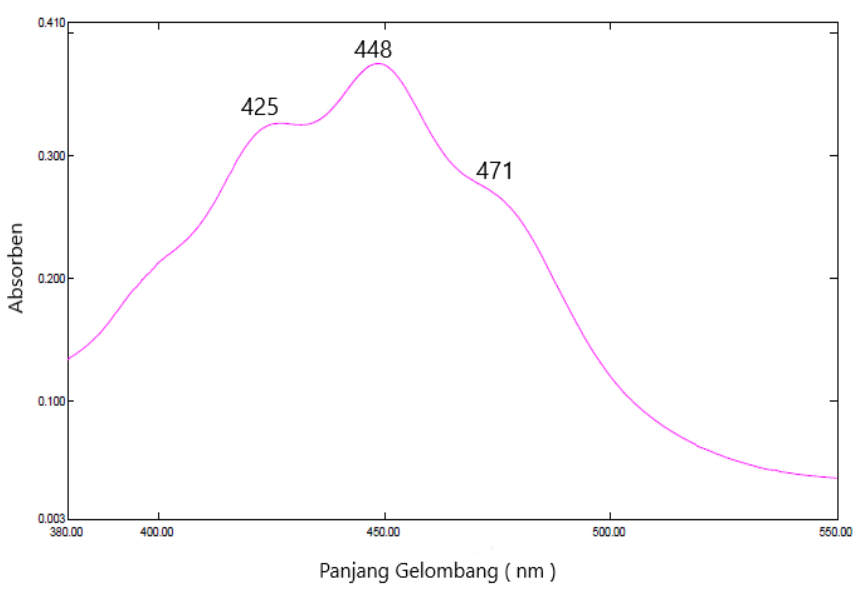

Gambar 5. Spektrogram Pigmen Jenis $\beta$ Karoten

Tabel 2. Jenis Pigmen Hasil Pemisahan Dengan Kromatografi Kolom

\begin{tabular}{cccc}
\hline FRAKSI & WARNA & $\begin{array}{c}\text { PANJANG GELOMBANG } \\
(\mathbf{n m})\end{array}$ & JENIS PIGMEN \\
\hline 1 & Kuning & $425,448,471$ & $\beta$-karoten \\
2 & Oranye pekat & 460 & Ekinenon \\
3 & Kuning & 470 & Astaxantin \\
4 & Oranye & 465 & Kantaxantin \\
5 & Oranye & 471 & Astasen \\
\hline
\end{tabular}


Maoka (2011) menyatakan metabolisme awal pada krustasea sering diawali dengan pembentukan pigmen $\beta$ karoten.

\section{Fraksi 2}

Fraksi 2 berwarna oranye pekat dan membentuk satu puncak serapan spektrofotometer pada panjang gelombang $460 \mathrm{~nm}$. Menurut Britton et al (1995), pigmen tersebut teridentifikasi sebagai pigmen Ekinenon. Hasil enelitian Paransa dkk, (2002) kepiting G. albolineatus betina yang ditangkap di daerah perbatasan Kalasey-Manado juga ditemukan pigmen ekinenon yang dipisahkan menggunakan larutan pengembang $\mathrm{PE}$ dan Aseton dengan perbandingan 80:20 menggunakan kromatografi Lapis Tipis. Hasil spektrogram fraksi 2 tampak pada Gambar 6.

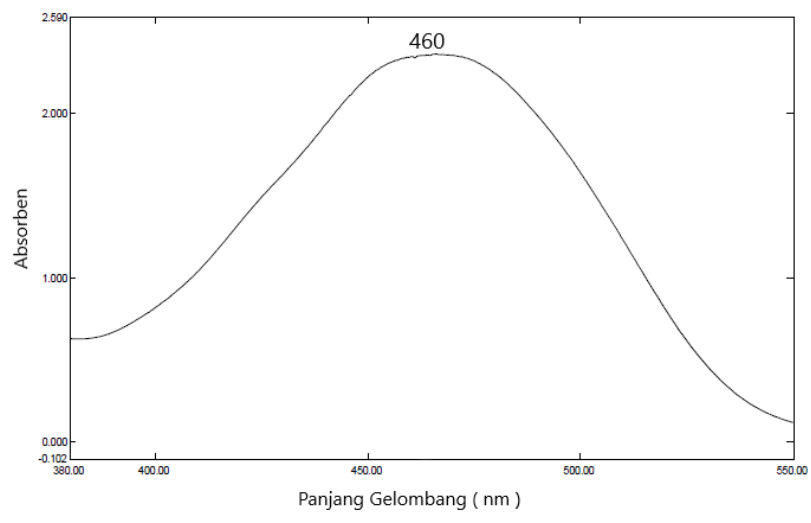

Gambar 6. Spektrogram Jenis Pigmen Ekinenon

\section{Fraksi 3}

Fraksi 3 berwarna kuning dan membentuk satu puncak serapan maksimum spektrofotometer dengan panjang gelombang $469 \mathrm{~nm}$. Menurut Britton et al (1995) bahwa serapan maksimum panjang gelombang pada 469 $\mathrm{nm}$ teridentifikasi sebagai pigmen astaxantin. Ruppert dan Barnes (1994) menyatakan bahwa pigmen astaksantin merupakan salah satu pigmen mayor yang ada pada krustasea, Astaxantin juga merupakan salah satu jenis pigmen karoten utama yang dapat ditemukan pada karapas kepiting khususnya Grapsus sp. Hasil spektrogram dari fraksi 3 tampak pada Gambar 7.

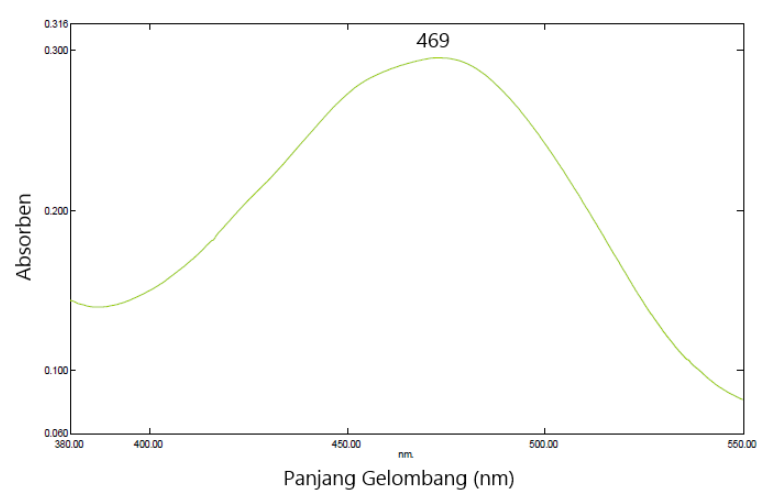

Gambar 7. Spektrogram Pigmen Astaxantin

\section{Fraksi 4}

Fraksi 4 membentuk satu puncak serapan maksimum spektrofotometer pada panjang gelombang $465 \mathrm{~nm}$ dan berwarna oranye. Menurut Britton et al. (1995) pigmen ini teridentifkasi sebagai pigmen jenis kantaxantin (Gambar ). Menurut Paransa dkk (2002), pigmen kantaxantin bermigrasi dibawah pigmen ekinenon pada hasil pemisahan Kromatografi Lapis Tipis. Pada penelitian ini pigmen kantaxanthin juga bermigrasi di bawah pigmen astaxantin dengan pemisahan menggunakan Kolom Kromatografi. Hasil spektrogram fraksi 4 ditampilkan pada Gambar 8.

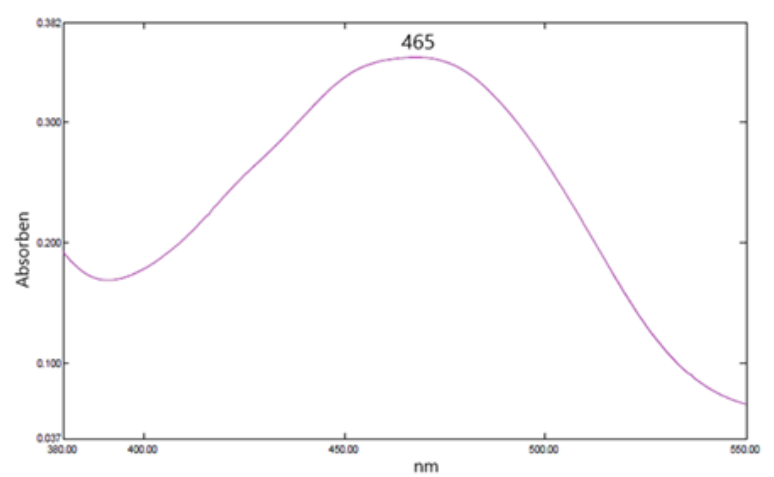

Gambar 8. Spektrogram Pigmen Jenis Kantaxantin

\section{Fraksi 5}

Fraksi 5 dengan warna oranye terbentuk satu puncak serapan 
spektrofotometer pada panjang gelombang $471 \mathrm{~nm}$. Menurut Britton et al (1995) pigmen pada panjang gelombang ini teridentifikasi sebagai pigmen jenis astasen. Hasil penelitian Makalalag (2017) jenis pigmen ini ditemukan pada fraksi ke 3 dengan puncak serapan spektrofotometer pada panjang gelombang $475 \mathrm{~nm}$ menggunakan metode Kromatografi Lapis Tipis. Serapan maksimum spektrofotometer dari pita 5 tampak pada Gambar 9.

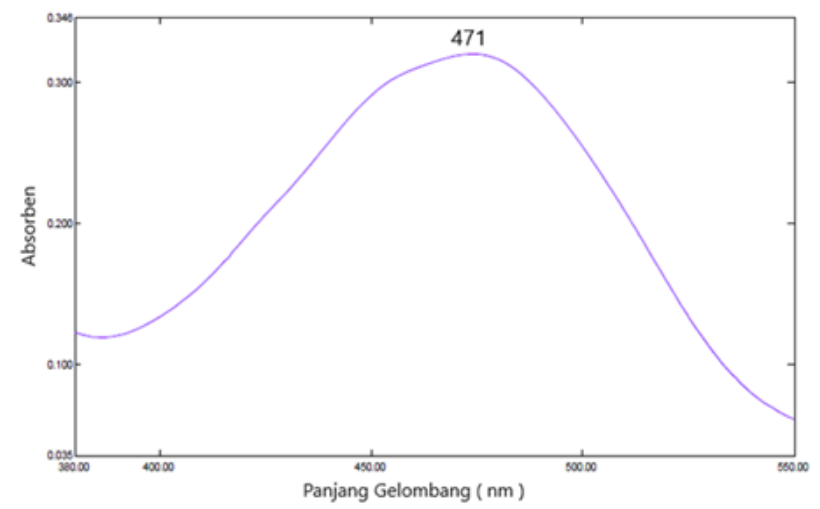

Gambar 9. Spektrogram Pigmen Jenis Astasen

\section{KESIMPULAN}

Dari hasil penelitian ini, dapat ditarik kesimpulan sebagai berikut: Kandungan pigmen karotenoid pada karapas 1,2 dan 3 adalah 46,85 $\mu \mathrm{g} 39 \mu \mathrm{g}$, dan 33,14 $\mu \mathrm{g}$. Konsentrasi pigmen karotenoid pada ekstrak karapas 1,2 dan 3 adalah 25,38 $\mu \mathrm{g} / \mathrm{g}, 23,4 \mu \mathrm{g} / \mathrm{g}$ dan 5,11 $\mu \mathrm{g} / \mathrm{g}$. Dari hasil pemisahan menggunakan metode kromatografi kolom jenis pigmen yang teridentifikasi dari ekstrak karapas kepiting Grapsus sp jantan adalah $\beta$ Karoten, Ekinenon, Astaxantin, Kantaxantin dan Astasen

\section{DAFTAR PUSTAKA}

Abdullah, M.R.A,. D.S.J. Paransa,. D.M.H. Mantiri,. E.D. Angkow. P.A. Angmalisang,. J.D. Mudeng. 2018. Distribusi Pigmen Karotenoid pada kepiting Grapsus sp dengan menggunakan Kromatografi Lapis Tipis. Jurnal Pesisir dan Laut Tropis. Volume 2 No.1. Hal 19-25

Bliss, D.E. and L. H. Mantel. 1985. Integument,

Pigments, and
Hormonal Processes. Vol 9, New York. America. Hal 45-48.

Bintang, M. 2010. Biokimia - Teknik Penelitian. Penerbit Erlangga. Bogor. $256 \mathrm{Hal}$

Britton, G., S.L. Jansen and H. Pfander. 1996. Carotenoids. Volume 2. Synthesis. Basel, Switzerland.

Majchacheep, S. 1989. Marine Animal Of Thailand. Published By Prae Pittaya. Thailand.

Makalalag, S., Paransa J.S.D., Mantiri, D.M.H. $2017 . \quad$ Penentuan Kandungan Pigmen Karetenoid pada Kepiting Grapsus albolineatus (Lamarck) Betina dari Perairan Pesisir Pantai Desa Tanawangko. Jurnal Pesisir dan Laut Tropis, 3 (1) : 1-9.

Mantiri, D.H.M., dan B. Kepel. 1999. Beberapa Peranan Pigmen Karatenoid. Jurnal Fakultas Perikanan dan IImu Kelautan. Volume 1 No. 3 Oktober 1999 Perairan pesisir Pantai Tanawangko. Jurnal pesisir dan Laut Tropis, 3 (1) :1-9

Maoka, T. 2011. Carotenoids in Marine Animals. Review. Jurnal Research Institute for Production Development. J.Marine Drugs. ISSN 1660-3397 - 9. Japan. Hal 278-293.

Paransa, D.S.J., Mantiri, D.H.M. Korompis, F. 2002. Penentuan Kandungan Pigmen Karatenoid Pada Kepiting Grapsus albolineatus Betina Berdasarkan Beda Larutan Pengembang Pada Kromatografi Lapis Tipis. Jurnal Perikanan Dan IImu Kelautan. Hal 1-10. Vol 1. No. 3. 2002.

Paransa D. S. J., Mantiri D. M. H., Lumenta C., Ompi M., Pratasik S. B., 2019 Morphological and genetic characteristics of lightfoot crab Grapsus albolineatus Latreille in Milbert, 1812 from Manado Bay, North Sulawesi. AACL Bioflux 12(3):804-811.

http://www.bioflux.com.ro/aacl 
Poore, C.B Gary. 2004. Marine Decapode Crustacea Of Southern Australia. A Guide To Indentification. CSIRO Publishing. Australia. 578 hal

Poupin J dan M. Juncker. 2010. A Guide To The Decapod Crustaceans of The South Pasific. Noumea, New Caledonia. Hal 319.

Ruppert E.E and Barnes R. D. 1985. Invertebrate Zoologi. Sixth Edition. Clemson University, Soutcorolini. Gettysburg College, Pennsylvania. $1056 \mathrm{Hal}$

Skinner M. Dorothy., 1962. The Structur and Metabolism of a crustacean integumen tissue during a molt cycle. Thw Biological Laboratoris. The Biological Bulletin. Departemant of Physiology and Biophysics. New York University School of Medicine. New york. Vol 123; Issue; Pages 635 - 647

Skinner, M. Dorothy dan S.Sindhu Kumari.1992. Proteins of The Crustacean eksoskeleton. Biophysics Department-Biology Division. Johnson City, Tennessee. Jurnal Amer Zoology 32: Hal 470484

Stahl, E. 1985. Analisis Obat Secara Kromatografi dan Mikroskopi. Penerbit ITB JL. Genesa Bandung. $267 \mathrm{Hal}$.

Vílchez. C, Forján. E, Cuaresma. M, Bédmar. F, Garbayo. I and Vega. J. M. 2011. Marine Carotenoids: Biological Functions and Commercial Applications. Journal Marine Drugs. Vol 9. Hal : 319333.

Zeak,W. L., Paransa, D. S. J., Rumengan, A., Kemer K., Paulus J.J.H., Mantiri D.M.H. 2019. Skrining Pigmen Karotenoid Pada Kepiting Grapsus sp. Dengan Menggunakan Pemisahan Kromatografi. Jurnal Pesisir dan Laut Tropis, 1 (1) : 52-58 